\title{
IFRS Adoption and Foreign Direct Investment: Evidence from Nigerian Quoted Firms
}

\author{
Jinadu, Olugbenga ${ }^{*}$ \\ Ojeka, Stephen Aanu (PhD)² \\ Ogundana, Oyebisi Mary ${ }^{3}$ \\ 1, 2, 3.Department of Accounting, Covenant University, Ota, Ogun State, Nigeria \\ jinaduolugbenga@gmail.com; stojeka@yahoo.com; ogundanaoyebs@yahoo.com
}

\section{Doi:10.5901/mjss.2016.v7n2p99}

\begin{abstract}
This study examines whether International Financial Reporting Standards (IFRS) adoption has impacted significantly on Foreign Direct Investments (FDI) in Nigeria. The study specifically investigates the views of the preparers and users of annual reports based on the impact of foreign investors on quoted companies that adopted IFRS in Nigeria. The primary method of data collection was adopted with 165 questionnaires administered while Regression method was used for data analysis. The findings revealed that the adoption of IFRS is positively and significantly related to FDI. The result also showed a significant impact of foreign investors on quoted firms that have adopted IFRS in Nigeria. The study recommends that the government should create an enabling environment to encourage investors, so as to attract foreign direct investments for the enhancement of economy status of Nigeria.
\end{abstract}

Keywords: Foreign direct investment, IFRS adoption, Nigerian economy, Quoted firms, Traditional economic theory

\section{Introduction}

The increase in the growth of international business, and financial transactions across borders call for IFRS adoption (Armstrong, Barth, Jagolinzer\&Riedl, 2010) for the following reasons: promotion of uniformity and transparency of reporting; harmonisation of standards for the purpose of consistency and comparability of annual reports leading to a boost in the investment potential of countries.

Nigeria adopted International Financial Reporting Standards (IFRS) in September, 2010 but the process commenced with companies listed on the Nigerian stock exchange for financial years commencing January 1, 2012. Other significant interest companies adopted IFRS in January 2013 while Small and Medium-sized Entities (SMEs) equally adopted it in January 2014. The adoption was organized such that all stakeholders use IFRS by January, 2014. This was done to ensure agreement in financial reporting practices between countries. It is also to enable government to show financial statements from various sources supported by IFRS as similar (Ramanna \& Sletten, 2009). The IFRSs are standards set by the International Accounting Standards Board (IASB) responsible for overseeing the convergence of accounting standards and high quality financial statements worldwide. Before the emergence of IFRS, many countries used local standards issued by their accounting bodies (Okpala, 2012).

Gordon, Loeb and Zhu (2012) opined that financial statements' preparation in line with IFRS enhanced the transparency of stewardship reporting and thus improved the investment ability of countries affected. This means that IFRS adoption will give stakeholders more assurance in the financial statements since they are in line with the international standards. Foreign direct investment therefore emerges due to the elimination of hindrances across country borders and improved trade between countries (Adetula, Nwobu\&Owolabi, 2014). Based on IMF (2004), Foreign Direct Investment (FDI) also arises due to an investment in an organization's business by an investor from a foreign country. Hossein and Yazdan (2012) also saw FDI as the main channel for the growth in economy through technological transfer.

The significant disparities in accounting standards cause information inequality between local and foreign investors as foreign investors do not possess a vivid knowledge of environmental factors. As a result of this, barriers with respect to information across countries' investments occur (Pagano, Roell \& Zechner, 2002); and foreign investors have to pay the penalty prize in transacting businesses with the local investors (Gordon \& Bovenberg, 1996). In the light of this, there is sparing flow of investors' interest to Nigeria due to an insignificant relationship between IFRS adoption and FDI (Adetula, Nwobu \& Owolabi, 2014; Emeni, 2014). Another limitation is that, studies also considered the determination of variables 
without attention being paid to the perceptions of stakeholders of financial statements of quoted companies (Adetula, Nwobu \& Owolabi, 2014; Emeni, 2014; Ramos, 2008).

The central objective of this study is to examine whether or not IFRS has impacted significantly on foreign direct investment since its adoption in Nigeria by analysing the views of preparers and users of annual report. This is necessary so as to check if there has been any noticeable transformational change in economic activities among countries which in turn should result to growth in the chance of cross-country investments. It is also set to ascertain how IFRS adoption affects the rate of FDI among quoted firms that have implemented IFRS in Nigeria.

\section{Literature Review}

This chapter discusses IFRS adoption and foreign direct investments in Nigeria. It also presents the empirical and theoretical frameworks for the study.

\subsection{IFRS adoption and Foreign Direct Investments in Nigeria}

The IFRS adoption in Nigeria was put into operation by Senator Jubriel Martins-Kuye in September, 2010 (Madawaki, 2012). The adoption commenced with significant public interest companies in 2012 and at 2014 year end, all parties were expected to comply. Today, listed sectors have fully put into practice IFRS. FDI is therefore defined by Kumar (2007) as the building of relationships with organisations through the injection of equity financing and reinvestment of earnings.

To be categorized as an international company for inclusion in FDI information, the parent must hold an equity share of 10 per cent minimum in the affiliate (Kumar, 2007). FDI enables a technology transfer and knowledge that are unavailable to local investors (DeGregorio, 2003; Oyetayo, Arogundade, Adebisi \& Oluwakayode, 2011).

The gradual adoption of IFRS in many countries reduces and eliminates the costs of gaining information for decision-making, as listed companies use the same standard of reporting in all the affected countries. In this way, IFRS therefore assists participants in the international markets and encourage the inflows of foreign capital to the adopting countries. Despite this important attribute, researchers analyse the benefits from the investors' perspective (Ball, 2006; Barth, Landsman \& Lang, 2008; Armstrong, Barth, Jagolinzer\&Riedl, 2010).

There are proponents and opponents who argue in favour and contrary to IFRS adoption. According to Barth, Landsman and Lang (2008), the adoption of IFRS is required to minimise the cost of financial information processing, ensuring consistency with one standard by smoothening the job of investment analysts, and arouse the interest of foreign investors. Lipsey and Chrystal (2003) remarked that FDI often creates higher-paying jobs for local citizens, it also creates investment that may not be possible with the local resources only, and it changes country's comparative advantages and enhances competition through technological transfer. GAB (2012) noted the disadvantages of adopting IFRS as including the forgoing benefits of any past and future innovations in local reporting standards specific to their economies. Although, many countries faced difficulties in their quest for IFRS adoption, but its universal adoption has been popularised on the premise that the gains go beyond costs (lyoha \& Faboyede, 2011).

\subsection{Empirical Review}

The first detailed study of IFRS and FDI was performed by Ramos (2008) on EU countries. The author employs a gravity model. The findings reveal that IFRS adoption positively influenced FDI. Another approach was adopted by Farooque, Yarram, and Khandaker (2009) who examine corporate governance and FDI inflows on the sample of twelve year data of 173 countries. The results indicate that IFRS increase the attribute of governance and allows unconstrained flow of capital.

Beneish, Miller and Yohn (2010) discover that IFRS adoption in the European Union has significantly impacted on foreign direct investment. Chen, Ding and Xu (2014) also examine the effect of IFRS adoption on FDI in OECD countries. They discover that the movement from local standards to IFRS contribute positively to the growth of FDI for the period of five years. According to Emeni (2014), FDI and IFRS adoption in Africa, shows that foreign direct investment is positive, but not significantly related to IFRS adoption due to scanty flow of FDI in Africa. Similarly, Adetula, Nwobu, and Owolabi (2014) look into the impact of IFRS adoption on FDI on Nigerian economy. The result shows that the longer a country uses IFRS the greater the FDI. 


\subsection{Theoretical Framework}

The theory underpinning this study rests on traditional economic theory where FDI is envisaged to be beneficial for the growth of the country's economy. According to theory, FDI will centre on developing countries, like Nigeria, where good opportunities exist for higher returns. For FDI to achieve its useful results, the following requirements must exist: the presence of human resources (Borensztein, De Gregorio \& Lee, 1998), better local facilities (De Mello, 1999), and an established domestic financial system (Alfaro, Kalemli-Ozcan, \& Sayek, 2006). The last requirement appears to be more influential for FDI to flow into developing countries and have a significant importance of economic growth. Lack of these necessities has culminated into inequality in the FDI spread across developing countries.

FDI is considered as an essential avenue for direct technology distribution and a major channel for technological transfer consequent upon the dearth of fund in less advanced countries (Hossein \& Yazdan, 2012). Within this framework, it is anticipated that FDI will improve the growth of the economy through the transfer of technologies (Hossein \& Yazdan, 2012). The IFRS adoption by Nigeria is an economic reform programme by government and standard setters to increase FDI flow to Nigeria. This is why it is important to study whether the adoption has yielded positive and significant result between the two variables. The above and prior findings with regard to IFRS adoption and foreign direct investments lead to the following hypotheses:

Hypotheses Statement

$\mathrm{H}_{1}$ : there is no significant relationship between IFRS adoption and FDI in Nigeria.

$\mathrm{H}_{2}$ : there is no significant impact of foreign investors on companies that have adopted IFRS in Nigeria.

\section{Research Methods}

This study adopted a survey research design method with reasons lying in the fact that it focuses on obtaining subjective opinion of respondents and aims at drawing an accurate assessment of the entire population by studying samples derived from the population usually in the form of questionnaire (Osuala, 2005). The primary method of data collection was also adopted to harness the views of the preparers and users of annual reports of quoted firms in Nigeria that consist of population. The preparers are 173 active quoted firms in Nigerian Stock Exchange represented by Finance Managers responsible for financial statements' preparation and are chosen as respondents on the basis of their involvement and awareness of IFRS. The users of financial reports are 225 investors that are represented by Investment analyst firms identified from the data structure of Capital market operators by the Nigerian Stock Exchange (lyoha \& Faboyede, 2011). Investment Analysts are chosen as respondents for being major users of annual reports (Mangena, 2004), they possess good knowledge of investment, that helps the analysis of annual reports (Baker, 1998). They also provide analytical information that can meet the needs of their clients (Gebhardt, Reichadt \& Wittenbrink, 2004).

The stratified random sampling technique was adopted as the population was grouped into two categories of preparers and users of annual reports. A sample of 200 persons was chosen at random, representing $50.25 \%$ of the population using Yaro Yamane sampling determination technique on population size of three hundred and ninety eight people. A computer package, on excel, was programmed to select 200 random numbers within the specified range in proportion to the stratified share of the population. The number generated was utilised to choose the preparers and users of annual reports from the sample. This is to guarantee robustness of this study and sample representativeness.

The instrument used was a survey questionnaire designed on a 5-point Likert form scale options which was divided into two sections, from strongly agree to strongly disagree. 86 questionnaires were returned by the preparers of which 70 , representing $81 \%$ were useable. For the users, 114 questionnaires were returned, of which 95 , representing $83 \%$ were found useable. For the purpose of ensuring the validity of the questionnaire, as recommended by Bryman and Bell (2007), the questionnaire was reviewed by experts both within and outside the field of accounting (Okpala, 2012; Okafor \& Ogiedu, 2011) while Pilot survey was adopted for the reliability test and it yielded a correlation coefficient of 0.79. It was structured in line with the research questions and hypotheses of the study (Okpala, 2012). Regression method was used to analyse the data collected through the administration of questionnaire gathered from 165 respondents. Regression method was also used to examine the relationship and extent of the relationship between the foreign direct investment and IFRS adoption in Nigeria.

\subsection{Model Specification}

For the purpose of measuring the relationship between dependent and independent variables, a model adapted from the study of Emeni (2014) is hereby specified: 
The functional form of the model could be presented explicitly as:

Where:

UFS = Users of annual reports (Investment Analysts) as a proxy for foreign direct investment (FDI).

PFS = Preparers of annual reports (Finance Managers) as a proxy for IFRS adoption.

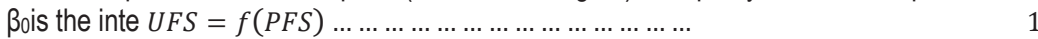

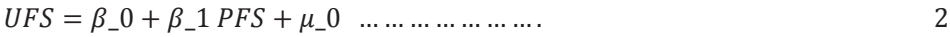

rcept of the regression line; $\beta_{1}$ is the slope of the regression line or behaviour parameters, each representing the unit change in the dependent variable due to a unit change in each regressor.

$\mu$ is the stochastic random error term that represents other independent variables that affect the model but not captured.

The model specified above captured users of financial statements (FDI) as dependent variables while preparers of financial statements (IFRS) as an independent variable.

\section{Result and Discussion}

\subsection{Result}

The result of the regression analysis for hypotheses is presented below.

\subsubsection{Test of Hypothesis}

\subsubsection{Hypothesis One}

$H_{1}$ : There is no significant relationship between IFRS adoption and FDI in Nigeria.

Regression Result

Dependent Variable: UFS1

Method: Least Squares

Sample: 1 to 15

Included observations: 15

\begin{tabular}{lclll}
\hline \hline \multicolumn{1}{c}{ Variable } & Coefficient & Std. Error & T-Statistic & Prob. \\
& & & & \\
\hline \multicolumn{1}{c}{ PFS1 } & 1.201084 & 0.122346 & 9.817111 & 0.0000 \\
& 2.184826 & 3.151369 & 0.693294 & 0.5003 \\
& & & & \\
\hline \hline R-squared & 0.881144 & Mean dependent var & 19.00000 \\
Adjusted R-squared & 0.872001 & S.D. dependent var & 28.63564 \\
S.E. of regression & 10.24497 & Akaike info criterion & 7.615016 \\
Sum squared resid & 1364.472 & Schwarz criterion & 7.709423 \\
Log likelihood & -55.11262 & Hannan-Quinn criter. & 7.614011 \\
F-statistic & 96.37566 & Durbin-Watson stat & 2.920075 \\
Prob (F-statistic) & 0.000000 & &
\end{tabular}

Source: Authors' computation from E- view 7.0

The summary of the OLS regression result is represented in an equation form, thus: $U F S=\beta_{0}+\beta_{1} P F S+\mu_{0}$

$U F S_{1}=2.184826+1.201084 P F S_{1}$

S. $E=(3.151369)(0.122346)$

$t_{c a l}=(0.693294)(9.817111)$

$R^{2}=0.881144 ;$ Adj. $R^{2}=0.872001 ; \mathrm{DW}=2.920075 ;$ F-stat. $=96.37566 ;$ Prob (F-stat. $)=0.0000$

From the regression results, the t-test revealed that a preparer of annual reports is statistically significant in explaining the variation in users of annual reports at $5 \%$ level of significance. This is as a result of the calculated t-test value (9.817111) against the $p$-value $(0.000)$ which is lesser than the test of significant at $5 \%$. The overall regression test, 
which is the F-statistic, revealed that the p-value (0.000) of the calculated F-statistic (96.37566) is lesser than the test of significance at $5 \%$. This shows that the regression result is positive and statistically significant at the $5 \%$ level.

Decision: the null hypothesis is rejected and it is concluded that there is a significant relationship between IFRS adoption and FDI in Nigeria

\title{
4.1.1.2 Hypothesis Two
}

$\mathrm{H}_{2}$ : there is no significant impact of foreign investors on companies that have adopted IFRS in Nigeria.

\author{
Regression Result \\ Dependent Variable: UFS2 \\ Method: Least Squares \\ Sample: 1 to15 \\ Included observations: 15
}

\begin{tabular}{lclcc}
\hline \hline \multicolumn{1}{c}{ Variable } & Coefficient & Std. Error & T-Statistic & Prob. \\
\hline \hline \multicolumn{1}{c}{ PFS2 } & & & & \\
\multicolumn{1}{c}{ C } & 1.361196 & 0.010287 & 132.3231 & 0.0000 \\
& -0.056745 & 0.249529 & -0.227408 & 0.8236 \\
\hline \hline R-squared & & & & \\
Adjusted R-squared & 0.999258 & Mean dependent var & 19.00000 \\
S.E. of regression & 0.999201 & S.D. dependent var & 27.92081 \\
Sum squared resid & 0.789215 & Akaike info criterion & 2.488009 \\
Log likelihood & 8.097180 & Schwarz criterion & 2.582416 \\
F-statistic & -16.66007 & Hannan-Quinn criter. & 2.487004 \\
Prob (F-statistic) & 17509.40 & Durbin-Watson stat & 1.599280 \\
& 0.000000 & & \\
\end{tabular}

Source: Authors' computation from E- view 7.0

The summary of the OLS regression result is stated below:

$U F S_{2}=-0.056745+1.361196 P_{F S}$

S. $E=(0.249529)(0.010287)$

$t_{\text {cal }}=(-0.227408)(132.3231)$

$R^{2}=0.999258 ;$ Adj. $R^{2}=0.999201 ; \mathrm{DW}=1.599280 ;$ F-stat. $=17509.40 ;$ Prob (F-stat. $)=0.0000$

From the above result, the overall regression test, which is the F-statistic, also revealed that the $p$-value $(0.000)$ of the calculated F-statistic (17509.40) is lesser than the test of significance at $5 \%$. This shows that the regression result is statistically significant.

Decision: the null hypothesis is rejected and it is also concluded that there is significant impact of foreign investors on companies that adopted IFRS in Nigeria.

\subsection{Discussion of Result}

The research work rests on the impact of IFRS adoption on foreign direct investment in Nigeria. The results of hypotheses tested revealed positive and statistical significance between IFRS adoption and FDI in Nigeria. This will boost the investors' confidence and leads to cross country financial transactions. It will also improve international accounting as a sub-discipline within the practice of accountancy (Glautier \& Underdown, 2001).

The preparers of financial statements as a proxy for IFRS adoption have a positive and significant effect on foreign direct investment in Nigeria. The value of regression coefficient or slope of both analyses is approximately equal to 1.201 and 1.361 which means that a $1 \%$ increase in IFRS adoption will cause as much as $120.1 \%$ and $136.1 \%$ rise in foreign direct investment on the Nigerian economy within the period considered. The overall evidence strongly suggests that the adoption of IFRS leads to a significant increase in FDls which is consistent with the primary objective and in agreement with Beneish, Miller and Yohn (2010) that the IFRS adoption in the European Union significantly increases foreign direct investment. Similarly, it is also in agreement with Pius, Jane, and Raymond, (2014) that the adoption of IFRS in Nigeria 
enhances credible financial statements that will provide a basis for the strength of public interest companies in the capital market. There is presence of no autocorrelation in the analysis due to the Durbin-Watson statistic value. This means that the regression analysis is not spurious. That is, the value of $\mathrm{R}^{2}$ is lesser than the Durbin-Watson Statistic value which shows that the analysis is perfectly okay.

\section{Conclusion and Recommendation}

\subsection{Conclusion}

In this study, attempts were made to examine the impact of foreign investors in companies that adopted IFRS in Nigeria. The traditional theory was used to develop the hypotheses tested in the study. On the basis of overall result, it could therefore be concluded that IFRS adoption is positively and significantly related to FDI, which is consistent with its primary objective and in agreement with Beneish, Miller and Yohn (2010) that the IFRS adoption in the European Union has significant impact on foreign direct investment.

\subsection{Policy implication}

The result revealed a positive and statistical significance between IFRS and FDI in Nigeria. There is also a noticeable impact of foreign investors on companies that adopted IFRS in Nigeria. This shows that the adoption of IFRS leads to a significant increase in foreign direct investment, as a 1\% increase in IFRS causes as much as $120.1 \%$ and $136.1 \%$ rise in FDls on Nigerian economy. It therefore shows a need for a policy shift in favour of foreign direct investments (FDI) to Nigeria if IFRS is to be more embraced.

\subsection{Policy Recommendation}

On the basis of the foregoing, the study hereby recommends that the government should create an enabling environment to encourage investors, so as to attract foreign direct investments for the enhancement of economy status of Nigeria. This process will yield more genuine annual reports that will provide a basis for true interpretation, as it will boost investors' trust and arouse the desire for international financial transactions.

\section{References}

Adetula, D.T., Nwobu, O. and Owolabi, F. (2014). International financial reporting standards and foreign direct investment in Nigeria, International Journal of Commerce, Business and Management (IJCBM), 3 (3): 446-449

Alfaro, L.,Chanda, A., Kalemli-Ozcan, S. and Sayek, S. (2006). How does foreign direct investment promote economic growth? Exploring the effects of financial markets on linkages. Cambridge, MA, USA. NBER Working Paper, 12522.

Armstrong, C. S, Barth, M. E, Jagolinzer, A. D, Riedl, E. J. (2010).Market reaction to the adoption of IFRS in Europe. The Accounting Review, 85 (1): 31-61.

Baker, R. G. (1998). The market for information evidence from finance directors, analysts and fund managers. Accounting and Business Research, 29 (1): 3-20.

Ball, R. (2006). International financial reporting standards (IFRS): Pros and cons for investors, Accounting and Business Research, 36 (1): 5-27.

Barth, M., Landsman, W and Lang M. (2008). International accounting standards and accounting quality. Journal of Accounting Research, 46: 467-498.

Beneish, M. D., Miller B. P. and Yohn T. L. (2010). IFRS adoption and cross border investment in equity and debt markets. Working Paper. Available at $h$ ttp://ssrn.com/abstract $=1403451$

Borensztein, E., DeGregorio, J. and Lee, J.W. (1998). How does foreign direct investment affect economic growth? Journal of International Economics, 45:115-135.

Bryman, A and Bell, E. (2007). Business research methods. USA: Oxford University Press.

Chen, C. J. P., Ding Y., andXu, B. (2014). Convergence of accounting standards and foreign direct investment. The International Journal of Accounting, 49 (1): 53-86

Coleman, J. S. (1990). Foundations of social theory, Cambridge, Belknap Press of Harvard University, 241-527

DeGregorio, J. (2003). The role of FDI and natural recourses in economic development. Working paper No. 196. Santiago, Central Bank of Chile

De-Mello, L.R. (1999). Foreign direct investment-led growth: Evidence from time series and panel data. Oxford Economic Papers, 51 (1): 133-151. 
Emeni F, K. (2014). Foreign direct investments and international financial reporting standards adoption in Africa. Ushus Journal of Business Management, 13 (3):27- 41

Farooque, O.A., Yarram S. R. and Khandaker, S. (2009).International evidence on governance and foreign direct investment interactions, Singapore economic review conference, 06-08 August 2009.

GAB (2012).The state of IFRS in Africa: Is IFRS in disarray? Governance across border. Available at http://www.governanc exborders.com

Gebhardt.G., Reichadt, R. and Wittenbrink, C. (2004). Accounting for financial instruments in the Banking Industry: Conclusion from a Simulation Model. European Accounting Review. 13(2): 341-371

Glautier M.W.E. and Underdown, B. (2001). Accounting theory and practice,7th Ed.,Prentice Hall; Financial Times

Gordon, R. H. and Bovenberg, A. L. (1996), Why is capital so immobile internationally? Possible explanations and implications for capital income taxation, American Economic Review, 86 (5): 1057-1075.

Gordon, L.A., Loeb, M.P. and Zhu, Z. (2012).The impact of IFRS adoption on foreign direct investment. Journal of Accounting Public Policy, 31: 374- 398.

Hossein, S.M and Yazdan G. F. (2012).FDI and ICT effects on productivity growth in Middle East countries. Journal of Economics and Sustainable Development 3 (8): 111-121.

Iyoha, F.O and Faboyede, S.O. (2011). Adopting international financial reporting standards (IFRS) - A focus on Nigeria. International Journal of Research in Commerce and Management. 2(1): 35-40.

Kumar, A. (2007). Does foreign direct investment help emerging economies? Economist's View. FRB Dallas. Available at http://economistsview.typepad.com/economistsview

Li, S. (2010). Does mandatory adoption of International Financial Reporting Standards in the European Union reduce the cost of equity capital? The Accounting Review 85 (2): 607-636.

Lipsey, R. and Chrystal, A. (2003).Economics.10th Eds. New Delhi, Oxford University Press. 641-642.

Madawaki, A. (2012). Adopting international financial reporting standards in developing countries: The case of Nigeria. International Journal of Business and Management, 7 (3). Available at $h$ ttp://www.cosenet.org/ijbm.

Mangena, M. (2004). On the perceived importance of disclosure items in UK interim financial reports: Evidence from the investment analysts. Working paper series, Bradford University.

Munch, S.B. (2002). Accounting for local physiological adaptation in bio-energetic models: Testing hypotheses for growth rate evolution by virtual transplant experiments. Can. J. Fish.Aquat.Sci.59: 393-403.

Okafor, C. A. and Ogiedu, K. (2011). Potential Effects of the Adoption and Implementation of International Financial Accounting Standards(IFRS)in Nigeria. JORIND, 9 (2): 345-358.

Okpala, K.E. (2012). Adoption of IFRS and financial statement effects: The perceived implications on FDI and Nigeria economy, Australian Journal of Business and Management Research, 2 (5): 76-83.

Osuala, E. C. (2005). Research Methodology. Enugu: New Generation Books.

Oyetayo, E.O., Arogundade, K. K., Adebisi, S.O and Oluwakayode, E.F. (2011).FDI, export and economic growth in Nigeria. European Journal of Humanities and Social Sciences. 2(1): 66-86.

Pagano, M.,Roell, A. A. and Zechner, J. (2002). The geography of equity listing: Why do companies list abroad? Journal of Finance, 57 (6): 2651-2694

Pius, V.C.O., Jane, F.N.O., and Raymond, A.E., (2014).Impact of the IFRS adoption on stock market movement in Nigerian corporate organization. International Journal of Academic Research in Business and Social Sciences, 4 (9): 202-218

Ramanna, K. and Sletten, E. (2009). Why do countries adopt international financial reporting standards? Harvard Business School Working Paper 09-102: 1-46. Available at http://www.hbs.edu

Ramos, L. M. (2008). The effect of IFRS adoption on trade and Foreign Direct Investments, international trade and finance association, Working Paper, 19.

Rossi, S., and Volpin, P. F. (2004). Cross-country determinants of mergers and acquisitions, Journal of Financial Economics, 74 (2): 277-304.

Scott, J. (2000). Rational choice theory, in understanding contemporary society: Theories of the present, in., G. Browning, H. Haleli and F. Webster (Eds), London, Sage Publications.

Stainbank, L. and Peebles, C. (2006). The usefulness of corporate annual reports in South Africa: perception of preparers and users. Meditari Accountancy, 14 (1): 69-80 